\title{
Country-Level Governance Quality and Stock Market Performance of GCC Countries
}

\author{
Kennedy Prince MODUGU1 ${ }^{1}$ Juan DEMPERE ${ }^{2}$
}

Received: May 29, 2020 Revised: June 14, 2020 Accepted: July 03, 2020

\begin{abstract}
This study examines the association between governance quality at country level and stock market performance. Specifically, the study investigates the influence of control of corruption, government effectiveness, political stability and absence of violence, rule of law, regulatory quality, and voice and accountability on all-share index of the stock markets of the six Gulf Cooperation Council (GCC) countries. This study is anchored on two theories - the Efficient Market Hypothesis (EMH) and Institutional Theory. The study employs panel data spanning from 2006 to 2017. The findings show that political stability and absence of violence and rule of law exhibit a significant positive impact on stock market performance, while regulatory quality and voice and accountability have a significant, but negative relationship with stock market performance. The results imply that quality of governance in terms of rule of law and political stability devoid of violence have strong impact on stock market returns. Similarly, improved stock market returns are largely dependent on the efficiency of the institutional environment of market as investors are always wary of the inherent risks associated with the uncertainty of the market. This study has crucial policy implications for the government of the GCC countries and stock market participants.
\end{abstract}

Keywords: Country-Level, Governance, Quality, Stock Market, Performance

JEL Classification Code: G3, G38

\section{Introduction}

Quality governance plays a vital role in the stability, liquidity, and efficiency of the stock market of any country. With the persistence of global financial scandals involving high profile corporations, investors' sensitivity to the operations of companies has heightened on the one hand. On the other hand, investors now probe more into country governance quality as opposed to corporate governance policies. This is against the backdrop that companies do not operate in a vacuum; rather, they are affected by the governance

${ }^{1}$ First Author and Corresponding Author. Higher Colleges of Technology (HCT) Business School, Ras Al Khaimah Campus, United Arab Emirates [Postal Address: Ras Al Khaimah, United Arab Emirates] Email: kmodugu@hct.ac.ae

${ }^{2} \mathrm{HCT}$ Business School, Ras Al Khaimah Campus, United Arab Emirates. Email: jdempere@hct.ac.ae

(c) Copyright: The Author(s)

This is an Open Access article distributed under the terms of the Creative Commons Attribution Non-Commercial License (http://Creativecommons.org/licenses/by-nc/4.0/) which permits unrestricted noncommercial use, distribution, and reproduction in any medium, provided the original work is properly cited. systems of their host environments (Boadi \& Amegbe, 2017). The effectiveness of the corporate governance framework at the company level is dependent on the overall structure and quality of country-level governance systems in force in the environment of operations of such companies. Governance systems connote the institutional arrangements that regulate the markets. These institutions consist of legal, political, economic, and regulatory establishments that provide order and cohesion for business activities to thrive (Hooper, Sim, \& Uppal, 2009). The equitability of the legal process, the extent of political stability, the level of corruption, transparency and accountability are key definitional ingredients of quality governance and their propensity to superintend the operations of the stock markets and their actors.

The emerging economies of the Gulf Cooperation Council (GCC) countries have grown steadily in the last few decades. This growth is, in part, attributed to the development of their stock markets. For example, the MSCI GCC countries index rose from $-43.59 \%$ in 2006 to $16.71 \%$ (MSCI, 2018). This is, however, not without some downward trends in between. A plethora of governance and macroeconomic indicators also accounted for this feat. 
A number of studies have examined the link between firm-specific corporate governance attributes and stock market performance. The novelty of this study stems from the following grounds: first, although several studies have been conducted in the past, their primary focus had been on the association between firm-specific corporate governance and stock market performance. The present study sheds light on the country-level governance environment under which firm-specific corporate governance is implemented. Second, previous studies have focused predominantly on developed economies, but our study provides an emerging market perspective with a special focus on a regional bloc. Third, the sample employed in this study comprises annual data of six countries with complete relevant data for the period from 2006 to 2017. The dataset coverage will ensure that more robust policy recommendations can be made. In addition, countrylevel governance structures have remarkable informative power related to firm-level measures in explaining stock market performance (Krishnamurti et al., 2005; Doidge et al., 2007; Claessens \& Yurtoglu, 2013). Finally, country heterogeneity is considered as a key relevance of this study. This is an improvement on prior country-specific studies, which inhibit the generalization of findings.

\section{Literature Review}

In recent times, a growing literature has examined the link between existing country-level governance framework and stock market development. This is against the backdrop of the impact of a series of government's policy actions, political upheavals, and legislative instruments on stock market performance. Contrary to the widely-held belief that stock market development is primary a function of companyspecific governance mechanism, recent studies have shown a strong relationship between country governance mechanism and stock market performance. Prior studies (for example, Lehkonen \& Heimonen, 2015; Billmeier \& Massa, 2007; Eita, 2015; Bello, 2015; Boadi \& Amegbe, 2017) switch from the traditional firm-specific corporate governance to country governance mechanisms. There is no gain stating that overall effectiveness or otherwise of a country's governance institutions significantly influences investors' confidence in the stock market. Milyo (2012) reveals a significant relationship between the US stock market and its governance indicators. Political events within a country as well as its external political relations influence the level of stock market returns. Chiu, Chen and Tang (2005) show that foreign investors' reactions to the electioneering events in South Korea showed significant impact on the stock market. Political events have a strong significant association with the volume of trading activities and market returns (Frey \& Waldenstrom, 2004; Bailey, Heck \& Wilkens, 2005; Aktas \& Oncu, 2006; Beaulieu, Cosset, \& Essaddam, 2006).
From casual empiricism, political uncertainty, and civil unrest weaken investors' confidence on the stock markets of affected countries, as no investor, whether private or corporate, will commit funds into a politically-charged environment. For instance, the Arab Spring, which saw a large pro-democracy demonstrations against dictatorships in the Middle East and North Africa (MENA) region created a huge drop in economic activities in the MENA region leaving stock returns at their lowest ebb. The aftermath of this crisis still leaves Libya in an unending civil war and terror up until now (Lehkonen \& Heimonen, 2015). The riots started in Tunisia and spread to Egypt, Libya and several other countries within the region. This led to political uncertainty and instability in the entire region. Due to the interdependence of these countries, the unrest was transmitted from one country to another and investors became more apprehensive the contagious effect. For example, on January 27, 2011, Egypt's benchmark index, the EGX 30, dived 10\% and even the world's major markets in the USA, Europe and Asia tumbled because the protests were expected to continue moving to other oil producing countries in the area. The unrest in Egypt lasted for all of 2011 because the Egyptian military, which seized control of the government after the revolution, refused to release power to the democraticallyelected government (Lehkonen \& Heimonen, 2015). This action sheds about $50 \%$ of the EGX 30 index value between January 3, 2011, and January 2, 2012.

Bailey et al. (2005) investigate the impact of political risk associated with the Iraqi invasion of Kuwait on the riskadjusted returns of international mutual funds. Their findings reveal that shareholders of international equity mutual funds earn significant abnormal returns in the face of political turmoil at the time. A related study by Frey and Waldenstrom (2004) examined effects of political events on sovereign debt prices on the Zurich and Stockholm stock exchanges before and during the World War II. Their findings show a considerable symmetry in the price responses of both markets, thus reflecting the efficiency of the markets.

Hooper, Sim and Uppal (2009) use the famous international asset pricing models to examine the association between the quality of government institutions and global stock markets performance. The results reveal a significant relationship between the dependent and independent variables. These findings confirm that countries with betterdeveloped governance systems have stock markets with higher returns on equity and lower levels of risk. The results lend support for the view that a precondition for financial market development is the improvement of the institutions that govern the process of exchange.

Lombardo and Pagano (2000) investigate the link between legal institutions and stock returns. They document three main regularities. First, total stock market returns are positively correlated with overall measures of the quality 
of institutions, such as judicial efficiency and rule of law, but have no relationship with measures of shareholder rights, controlling for risk. Second, dividend yields and earning-price ratios also correlate positively with judicial efficiency and rule of law, but negatively with shareholder rights' protection, controlling for risk and expected earnings growth. Thirdly, the excess return on new issues is negatively associated with the quality of accounting standards. They conclude that there is positive influence of the aggregate quality of institutions on stock returns.

Low, Kew and Tee (2011) examines the relationship between quality of governance and stock market performance. The study shows a negative relationship between governance quality and equity return. The findings further reveal that countries with low governance scores, on average, have higher equity returns than those with high governance scores after controlling for global risk factors known to influence international equity returns. This suggests that investors associate low governance quality with increased risk and thus demand higher risk premium. They observe that that the quality of governance proxied by political stability and absence of violence is key governance variable that affects stock returns. This implies that increased investor concerns over political risks have significant impact on the equity markets.

Giannetti and Koskinen (2010) offer theoretical underpinnings for understanding why weak investor protection leads to lower level of expected returns. Their model proposes that in an environment with weak investor protection, wealthy investors have more incentives to acquire control, thus resulting in high demand for weak corporate governance stocks. Due to this high demand for stock, stock prices become exceptionally high to show a true reflection of the possibility of expropriation of private benefits by controlling shareholders. This model explains why weak investor protection attracts lower rate of stock returns. This assertion is in consonance with existing empirical findings that equity returns are lower in countries with weak investor protection (Gompers, Ishii \& Metrick, 2003; Cremers \& Nair, 2005; Core, Guay \& Rusticus 2006; Lombardo and Pagano, 2006; Yermack, 2006; Fan, Rui \& Zhao, 2008; among others).

Fan et al. (2008) prove that companies operating in countries bedeviled by weak public governance structure tend to finance their investments with more debt than equity. Since stock markets with poor governance structure have higher agency and transaction costs than those with good governance framework, and given that equity provides investors with lesser degree of monitoring than debt, demand of equity would decline in poorly governed markets resulting in lower returns on equity (Low et al, 2011). Gompers et al. (2003) also argue that poor governance leads to high agency costs associated with managerial perquisite consumption and overinvestment, leading to lower valuations by investors and, thus, lower returns. Further to this argument was the study by Lombardo and Pagano (2006). They observe a positive relationship between the quality of legal institutions and riskadjusted return on equity. They argue that the quality of legal institutions can increase equity return by reducing agency costs between managers and shareholders. This connotes that lower amount of private benefits expropriated by managers allows firms to offer higher rate of returns to investors. In addition, Chiou, Lee and Lee (2010) examine the association between stock return, risk and legal environment. Their finding reveal that efficient legal and political systems manifested by low corruption, high quality legal system, adequate investor protection, honest social and political environments would engender a significant increases in the performance of equity investment and decreases in risks. Similarly, Li and Filer (2007) agree that countries with better property rights protection, unbiased and transparent legal systems tend to attract more equity investors.

Despite the vast literature supporting the influence of political events and quality of governance institutions on stock market returns, some studies have however offered opposite conclusions. Ismail and Suhardjo (2011) report that there is no significant relation between domestic political events and stock market performance in Indonesia. Their findings show that neither the overall stock market nor any industry within the market exhibited any significant response to political event at the time. Chiu et al (2005) finds a negative relation between KOSPI 200 index return and political activities. Chavali, Alam and Rosario (2020) opine that the impact of electoral activities on stock market returns is partly due to stakeholders' expectations policy changes that may affect the operating environment of companies. This uncertainty may affect investors' confidence prior to actual voting and announcement of results. As a result, there is a possibility of stock market volatility due to investors' risk appetite (Nguyen \& Nguyen, 2019). While some may hold back on investable funds on account of perceived unfavorable returns, others may cash in on the uncertainty with anticipated surge in their returns post elections.

In their study, Javed and Ahmed (1999) investigate the impact of the nuclear tests in India and Pakistan between 1998 and 1999 on the stock performances of the Karachi Stock Exchange. The result reveal that Indian nuclear test shows a significant negative relation with KSE. On the contrary, the Pakistani test shows no significant impact in stock performance. Some studies have examined the impact of graft-induced institutional weakness on stock market development. For example, Bolgorian (2011) investigates the relationship between corruption and stock market development. The study shows a significant association between power-law dependence corruption level and stock market development. The findings also reveal a negative 
relationship between corruption and financial system improvement; confirming the theoretical proposition that a less corrupt institutional framework can lead to a virile financial system.

Interestingly, the literature on governance quality and stock market performance is predominantly focused on developed markets. An emerging market perspective of this study is imperative for a balance of opinion on the one hand. On the other hand, generalizing the findings of developed markets on the global market without concomitant scientific inquiries will amount to fallacy of hasty generalization. According to Billmeier and Massa (2007), relatively little of the recent research interest in financial markets has been directed at the Middle East and Central Asia, a region that comprises some of the richest countries in the world and endowed with vast resources of oil and gas. In the resource-rich Middle East, stock markets have experienced large fluctuations over the last few years. Despite these concerns, no considerable research attempt has been made to investigate the role of governance quality in the development of the stock markets of the perceivably rich GCC countries. Therefore, this is undertaken partly to bridge this gap.

\section{Theoretical Framework}

This study is anchored on two theories; the Efficient Market Hypothesis (EMH) and Institutional Theory. The origin of EMH dates back to the two separate works of Eugene F. Fama and Paul A. Samuelson in early 1960s. Interestingly, they individually developed the similar fundamental notion of market efficiency in their separate research plans. The EMH also known as the Random Walk Theory (RWT) is a proposition that current stock prices fully reflect all available information about the value of the firm, and there is no way excess profits can be maximized by a section of the market using the available information known to all participants in the market. The term "efficient market" was first used in Fama (1965). The study argues that in an efficient market, other things being equal, competition will foster instantaneous reflection of new information on actual stock prices. Investors and analysts commit substantial amount of resources in search of securities that are expected to appreciate in the future values. Using relevant forecasting and valuation algorithms and techniques, they identify stocks with undervalued present value but with anticipated increase in future prices that will outperform the market. Investors with better information and forecasting power can gain substantial profits from the outcome of such research. Unfortunately, the EMH argues that no analysis or technique is worth the research time and cost of the researcher. This is against the backdrop that since the information is available to all market participants, no one in the market can gain undue advantage over another as the gains do not exceed the research and transaction costs incurred. Thus, in an efficient market, profiting from price prediction is extremely difficult and not likely. The submissions of Samuelson (1965) that in an informationally efficient market, price changes must not be forecastable if they fully incorporate the information and expectations of all market participants summarily captures this view.

Researchers have conceptualized three variants of the Efficient Markets Hypothesis based on their individual definition of "all available information". They are the weak, semi-strong and strong forms of EMH. The weak form of the EMH posits that the current price incorporates fully information contained in the historical prices, as such; nobody can detect mispriced securities and beat the market by researching into historical prices. The semi-strong form of EMH suggests that the current price incorporates all information publicly available. Publicly available information comprises both historical prices and other financial and non-financial disclosures in corporate annual reports. The public nature of the information under this variant of EMH validates the unlikelihood of profiting from abnormal future prices. The strong form of EMH asserts that the current market price of stocks incorporate fully all existing information from both public and private sources.

Our study is anchored on the theoretical foundation that governance quality indicators are public information made available by the World Bank, and investors interrogate these indicators before making investment decisions. Therefore, the a priori expectation is that investors' perception of the ranking of these indicators will directly influence stock market investment decision and by extension, the stock market capitalization.

The second theoretical underpinning for our study is the Institution Theory. This is a socio-political theory that deals with the manner in which rules, norms, culture, policies and regulations are established and managed by a higher authority as authoritative guidelines for social behavior within an ecosystem. According to Scott (2004), institutions are social structures that have attained a high degree of resilience which consist of cultural-cognitive, normative, and regulative elements that, together with associated activities and resources, provide stability and meaning to social life. The fundament focus of the Institutional Theory is that the actions or inactions of individuals are structured by higher order authority above the individual level; which constrains or constitutes the interests and participation of actors (Clemens \& Cook, 1999). This theory fits into our study in that the stock market does not exist without institutional and regulatory environment. These governance structures influence the confidence of investors on the efficiency of the market and thus, determine their level of participation and the eventual impact on the stock market. 


\section{Methodology}

\subsection{Data Sources}

The data for the dependent variable (all share indexes) were collected from the World Bank Development Indicators for the GCC countries and show a vast representation of the each of the county's market composition. The all-share indexes, which represent the performance of the equities market, consist of the data from the major stock exchanges in the six GCC countries of Saudi Arabia, United Arabs Emirates, Bahrain, Kuwait, Oman and Qatar. The data cover the period from 2006 to 2017 corresponding to the years that data were available for the independent variables. The data for the independent variables (voice an accountability, control for of corruption, government effectiveness, rule of law, political stability and absence of violence and regulatory quality) as were obtained from the World Bank Governance Index (WGI) for the six selected countries as developed by Kaufmann and Kraay (2017). The WGI discloses both aggregate and individual governance indicators for 215 countries and territories for the six dimensions of governance stated above. In this study, governance is defined as the institutions through which authority in a country is exercised. This consists of the process by which governments are selected, monitored and replaced; the capacity of the government to effectively formulate and implement sound policies; and the respect of citizens and the state for the institutions that govern economic and social interactions among them. Kaufmann and Kraay (2017) rankings are based on over 30 underlying data sources reporting the perceptions of governance of a large number of survey respondents and expert assessments worldwide.

\subsection{Model Specification}

Table 1 reports the variables used in the study.

$$
\begin{aligned}
\mathrm{GOQ}= & \alpha_{0}+\alpha_{1} \mathrm{COC}_{\mathrm{it} 1}+\alpha_{2} \mathrm{GOV} \mathrm{EFF}_{\mathrm{it} 2}+\alpha_{3} \mathrm{PS}_{-} \mathrm{AV}_{\mathrm{it} 3}+ \\
& \alpha_{4} \mathrm{ROL}_{\mathrm{it} 4}+\alpha_{5} \mathrm{RQ}_{\mathrm{it} 5}+{ }_{+} \alpha_{6} \mathrm{VAC}_{\mathrm{it} 6}+\mu_{\mathrm{it}}
\end{aligned}
$$

Where:

$\mathrm{CC}$ is Control of Corruption,

GOV_EFF is Government Effectiveness,

PS_AV is Political Stability and Absence of Violence,

$\mathrm{ROL}$ is Rule of Law,

QR is Regulatory Quality and,

VA Voice and Accountability.

\section{Results and Discussion}

The data were analyzed using Eviews 11, a statistical package for data analysis, and the results are presented below.

\subsection{Descriptive Statistics}

Table 2 shows the summary statistics of the all share indexes of the six selected countries, which indicate the stock market performance for the period from 2006 to 2017. A total of 72 observations were employed. The results shows that Qatar has a maximum mean value of 9219.69, while Bahrain reveals the lowest mean value of 1519.11. More importantly, the standard deviation of the all share index for the six countries fell below the mean values, indicating normality of the data.

Table 3 shows the summary descriptive statistics of the panel data of both the dependent and the independent variables. The mean of all-share index (ASI) is positive indicating favorable stock returns over the period under investigation. The standard deviation of the ASI falls below the mean, which lends credence to the non-violation of the normality of the data distribution. The difference between the minimum and maximum values of the ASI indicates a significant positive growth in the stock returns. By definition, the mean values of the governance indicators should be zero as result of the standardized estimated values of -2.5 (weak) to 2.5 (strong).

Government effectiveness (GOV_EFF) has the highest positive mean value, followed by rule of law (ROL), regulatory quality (RQ), control of corruption (COC) and political stability and absence of violence. However, voice and accountability (VAC) has a negative mean value. The mean values of all the variables except for COC, PS_AV and VAC are higher the standard deviation indicating a good spread and high data quality. The results of the Levin, Lin and Chu test panel unit root tests (Appendix I) indicate that the series of the log of ASI are stationary at levels. This suggests that all the variables employed in the estimation exercise are appropriate, as the mean and variance of the variables are constant, justifying the predict power of the model. The line graph of the log differenced series of ASI (Appendix II) also shows a significant amount of stationarity as it revolves around the mean of 2.6.

Table 4 shows the estimation output of the relationship between the dependent and independent variables. Political stability and absence of violence (PS_AV) shows a positive impact on all-share index (ASI) and is significant at 5\% level. This implies that countries with higher perceptions of the likelihood of political instability and/or politicallymotivated violence, including terrorism are more likely to witness a surge in equities indexes. This negates the theoretical underpinnings that investment under uncertainty, induced by political conflicts, instability and terrorism will generally reduce. However, the study of Beaulieu, Cosset and Essaddam (2006) support the result of our findings.

The study observes that during the 1995 Quebec referendum in Canada, huge uncertainty surrounding the 
Table 1: Variables

\begin{tabular}{|c|c|c|c|c|}
\hline Variables & $\begin{array}{l}\text { Dependent/ } \\
\text { Independent }\end{array}$ & definition & Estimates & Sign \\
\hline All-share index & Dependent & Market capitalization weighted index & & \\
\hline $\begin{array}{l}\text { Voice and } \\
\text { Accountability }\end{array}$ & Independent & $\begin{array}{l}\text { Reflects perceptions of the extent to which a } \\
\text { country's citizens are able to participate in selecting } \\
\text { their government, as well as freedom of expression, } \\
\text { freedom of association, and a free media. }\end{array}$ & -2.5 to 2.5 & positive \\
\hline $\begin{array}{l}\text { Political Stability and } \\
\text { Absence of Violence }\end{array}$ & Independent & $\begin{array}{l}\text { Political Stability and Absence of Violence/Terrorism } \\
\text { measures perceptions of the likelihood of political } \\
\text { instability and/or politically-motivated violence, } \\
\text { including terrorism. }\end{array}$ & -2.5 to 2.5 & negative \\
\hline $\begin{array}{l}\text { Government } \\
\text { Effectiveness }\end{array}$ & Independent & $\begin{array}{l}\text { Reflects perceptions of the quality of public services, } \\
\text { the quality of the civil service and the degree of its } \\
\text { independence from political pressures, the quality } \\
\text { of policy formulation and implementation, and the } \\
\text { credibility of the government's commitment to such } \\
\text { policies. }\end{array}$ & -2.5 to 2.5 & positive \\
\hline Regulatory Quality & Independent & $\begin{array}{l}\text { Reflects perceptions of the ability of the government } \\
\text { to formulate and implement sound policies and } \\
\text { regulations that permit and promote private sector } \\
\text { development. }\end{array}$ & -2.5 to 2.5 & positive \\
\hline Rule of law & Independent & $\begin{array}{l}\text { Reflects perceptions of the extent to which agents } \\
\text { have confidence in and abide by the rules of society, } \\
\text { and in particular the quality of contract enforcement, } \\
\text { property rights, the police, and the courts, as well as } \\
\text { the likelihood of crime and violence. }\end{array}$ & -2.5 to 2.5 & positive \\
\hline Control of corruption & Independent & $\begin{array}{l}\text { Reflects perceptions of the extent to which public } \\
\text { power is exercised for private gain, including both } \\
\text { petty and grand forms of corruption, as well as } \\
\text { "capture" of the state by elites and private interests. }\end{array}$ & -2.5 to 2.5 & negative \\
\hline
\end{tabular}

Source: Researchers' Compilation from Kaufmann and Aart (2017)

Table 2: Summary Statistics for All Share Index

\begin{tabular}{|l|c|c|c|c|}
\hline \multicolumn{1}{|c|}{ Countries } & Mean & S.d. & Min. & Max. \\
\hline Saudi Arabia & 7440.69 & 1452.74 & 4802.99 & 11038.66 \\
\hline Bahrain & 1519.11 & 463.62 & 1065.61 & 2755.27 \\
\hline Oman & 5886.34 & 1218.05 & 3981.19 & 9035.46 \\
\hline Qatar & 9219.69 & 1590.06 & 6886.12 & 12285.78 \\
\hline UAE & 3747.44 & 1018.34 & 2390.01 & 5039.70 \\
\hline Kuwait & 4248.07 & 1200.87 & 3026.10 & 7622.42 \\
\hline
\end{tabular}

referendum outcome on the separation of Quebec from rest of the country sent huge shocks to indigenous Quebec firms that saw the reduction in market capitalization of those corporations. However, the shares of multinational companies were not affected because they were less susceptive to pessimistic scenarios. They were more concerned with the negative implications of abandonment of the Canadian currency, capital flight and cost of capital payment amongst others. Similarly, Abadie and Gardeazabal (2003) compare the stock value of firms located in Basque county to counterfactual firms located in other non-turbulent regions. They observed that the return from stocks of firms 
Table 3: Summary statistics for Dependent and Independent Variables

\begin{tabular}{|l|c|c|c|c|c|c|c|}
\hline & ASI & COC & GOV_EFF & PS_AV & ROL & RQ & VAC \\
\hline Mean & 5305.060 & 0.436 & 0.450 & 0.269 & 0.448 & 0.438 & -1.028 \\
\hline Maximum & 12285.78 & 1.567 & 1.509 & 1.224 & 0.959 & 1.111 & -0.485 \\
\hline Minimum & 1065.610 & -0.331 & -0.303 & -1.335 & 0.001 & -0.173 & -1.908 \\
\hline Std. Dev. & 2775.720 & 0.486 & 0.444 & 0.696 & 0.248 & 0.316 & 0.424 \\
\hline Observations & 72 & 72 & 72 & 72 & 72 & 72 & 72 \\
\hline
\end{tabular}

Table 4: Results of Panel Least Squares Regression

\begin{tabular}{|l|c|c|c|c|}
\hline \multicolumn{1}{|c|}{ Variables } & Coefficients & Std. Errors & t-Statistic & Prob. \\
\hline C & 3.024245 & 0.094038 & 32.15980 & 0.0000 \\
\hline COC & 0.073122 & 0.123276 & 0.593156 & 0.5551 \\
\hline GOV_EFF & -0.234876 & 0.128584 & -1.826639 & 0.0723 \\
\hline PS_AV & 0.342765 & 0.044948 & 7.625784 & 0.0000 \\
\hline ROL & 0.713959 & 0.142868 & 4.997348 & 0.0000 \\
\hline RQ & -0.487088 & 0.106360 & -4.579611 & 0.0000 \\
\hline VAC & -0.487554 & 0.061185 & -7.968543 & 0.0000 \\
\hline R-squared & \multicolumn{5}{|c|}{0.736284} \\
\hline Adjusted R-squared & \multicolumn{5}{|c|}{0.711941} \\
\hline S.E. of regression & \multicolumn{5}{|c|}{0.148921} \\
\hline Durbin-Watson stat & \multicolumn{5}{|c|}{0.863199} \\
\hline F-statistic & \multicolumn{5}{|c|}{0.24621} \\
\hline Prob(F-statistic) & \multicolumn{5}{|c|}{} \\
\hline
\end{tabular}

located in the Basque county increased at the beginning of the fourteen months long imbroglio but decreased at the end of the truce. In addition, Political activists may exploit political conflicts to gain political connections which may directly affect investors expected returns.

Rule of law (ROL) reveals a significant positive relationship with ASI. This indicates that a growth in stock market returns is driven by the confidence level of the members of a country in key institutions of governance such as the executive, legislature and judiciary as well as other administrative organs of government. Therefore, countries with higher ranking in rule of law record higher stock returns. The trustworthiness of government institutions reaffirms both existing and potential investors' confidence in the apparatuses of government to safeguard their investments. This agrees with finding of Djankov et al. (2003) and La Porta et al. (1999) that countries with strong judicial and administrative protection of investors record higher stock performance.

Regulatory quality (RQ), which measures perceptions of the ability of the government to formulate and implement sound policies and regulations that permit and promote private sector development, shows a significant, but negative association with ASI. The results indicate that countries with higher regulatory control experience a downward trend in stock market returns. This conforms to the findings of Boadi and Amegbe (2017) and Albuquerque and Wang (2008) that poor regulatory framework necessitates increased investment in the capital markets, especially for emerging economies. Wealthy investors take undue advantage of poor regulatory environment to manipulate the stock market leading to increased activity volume and market capitalization.

Voice and accountability (VAC) shows a significant, but negative relationship with ASI. This negates the a priori expectation and thus indicates that civil liberty does not translate into improvement in stock market returns. It implies that improvement in democratic practices does not lead to higher market capitalization. The GCC countries are monarchies and witnessed a steady growth in ASI over the period under investigation. The findings of this study reveal that freedom of speech, freedom of association, press and social media freedom as well as government accountability 
do not necessarily translate into equity returns. This confirms the findings of Lehkonen and Heimonen (2015).

Control of corruption (COC) and government effectiveness (GOV_EFF) show positive and negative impact on ASI respectively. Both relationships are not statistically significant at $5 \%$ level. Therefore, we cannot conclude that COC and GOV_EFF have appreciable influence on stock market performance. These results are in conflict with the findings Lee and $\mathrm{Ng}$ (2004) that countries with low level of corruption control records lower market multiples. The results also contradict Mauro (1995) which argues that corruption hampers stock market investment and growth, and Wei (1997) which asserts that countries with visible corruption attract insignificant amount of foreign direct investment since the prevalence of corruption erodes investors' confidence in the rules that guide their businesses and thus increases investors' risks aversion stock market.

The $\mathrm{R}^{2}$ of 0.736 indicates that the model explains about $73.6 \%$ of the total systematic variation in ASI. Adjusting for degrees of freedom, the model still explains about $71 \%$ of the total systematic variation in the ASI as only $26 \%$ and $29 \%$ of unexplained variations are captured by the stochastic error terms respectively. The Durbin-Watson stat statistic of 0.86 indicates the presence of serial autocorrelation. This is explained by the uniform ranking of between -2.5 to 2.5 range of the independent variables. However, this is does not dismiss the predictive power of the model.

\section{Conclusion and Policy Implications}

Stock market performance is an integral part of a country's financial health, and by extension its economic growth. In this study, we examined the impact of governance quality on stock returns. Specifically, the study investigated the influence of control of corruption, government effectiveness, political stability and absence of violence, rule of law, regulatory quality, and voice and accountability on all-share index in the six countries of the Gulf Cooperation Council.

The results of this study present some strategic implications for the regulatory authorities, financial institutions and investment professionals. First, the results demonstrate that quality of governance in terms of rule of law and political stability and absence of violence are statistically significant with stock market performance. Similarly, regulatory quality and voice and accountability show significant, but negative association with stock market performance. This indicates that improved stock market returns is largely dependent on an efficient institutional environment of the operators of the stock markets. Stock market investors are always wary of the inherent risks associated with the uncertainty of the market. As a result, investors with low-risk appetite will channel their investments into countries they perceive display a commendable amount of institutional and regulatory efficiency as this will help lower their agency and transaction costs and increase their investment returns. However, the significant, but negative relationship between regulatory quality and voice and accountability and stock market performance raises some concerns about the quality regulation and civil liberty, and thus, necessitates deliberate intervention of the government of the countries to smoothen the rough edges for the growth of the stock markets. This study, therefore, recommends to the governments of the GCC countries to rejig its regulatory policy framework at its highest level while also reforming its human rights and accountability initiatives in line with the global best practice.

\section{References}

Abadie, A., \& Gardeazabal, J., (2003). The economic costs of conflict: A case study of the Basque country. American Economic Review, 93, 113-132. doi.org.10.1257/000282803321455188

Aktas, H., \& Oncu, S. (2006). The stock market reaction to extreme events: the evidence from Turkey. International Research Journal of Finance and Economics, 6(6), 78-85.

Albuquerque, R., \& Wang, N. (2008). Agency conflicts, investment, and asset prices. Journal of Finance, 63, 1-40. https://doi. org/10.1111/j.1540-6261.2008.01309.x

Bailey, B. A., Heck, J. L., \& Wikens, K. A. (2005). International mutual fund performance and political risk. Review of Pacific Basin Financial Markets and Policies, 8(1), 167-184. https:// doi.org/10.1142/S0219091505000312

Beaulieu, M. C., Cosset, J. C., \& Essaddam, N. (2006). Political uncertainty and stock market returns: evidence from the 1995 Quebec referendum. The Canadian Journal of Economics, 39 (2), 621-641.https://doi.org/10.1111/j.0008-4085.2006.00363.x

Bello, A.K. (2014). Quality of governance and stock market performance: The Nigerian experience. Journal of Economics and Development Studies, 2(2), 501-522. http://jedsnet.com/ journals/jeds/Vol_2_No_2_June_2014/35.pdf

Billmeier, A. \& Massa, I. (2007). What drives stock market development in the Middle East and Central Asia: Institutions, remittances or natural resources? IMF Working Paper, WP/07/157. https://www.imf.org/external/pubs/ft/wp/2007/wp07157.pdf

Boadi, I. \& Amegbe, H. (2017). The link between quality of governance and stock market performance: International Level Evidence. European Journal of Government and Economics, 6(1), 78-101. https://www.ejge.org/index.php/ejge/article/ view/111

Bolgorian, M. (2011). Corruption and Stock market development: A quantitative approach. Physica, 390, 4514-4521 10.1016/j. physa.2011.07.024

Chavali, K., Alam, M., \& Rosario, S. (2020). Stock market response to elections: an event study method. Journal of Asian Finance, Economics and Business, 7(5), 9-18. https://doi.org/10.13106/ jafeb.2020.vol7.no5.009

Chiou, W. J. P., Lee, A. C. \& Lee, C. F. (2010). Stock return, risk, and legal environment around the world. International 
Review of Economics and Finance, 19, 95-105. https://doi. org/10.1016/j.iref.2009.05.001

Chiu, C. L., Chen, C. D., \& Tang, W. W. (2005). Political elections and foreign investor trading in South Korea's financial markets. Applied Economics Letters, 12, 673-677. https://doi. org/10.1080/13504850500190097

Claessens, S., \& Yurtoglu, B. B. (2013). Corporate governance in emerging markets: a survey. Emerging Market Review 15(1), 1-33. https://doi.org/10.1016/j.ememar.2012.03.002

Clemens, E. S. \& James M. C. (1999). Politics and institutionalism: explaining durability and Change. Annual Review of Sociology 25, 441-466.

Core, J. E., Guay, W. R. \& Rusticus, T. O. (2006). Does weak governance cause weak stock returns? An examination of firm operating performance and investors' expectations, Journal of Finance, 61, 655-687. https://doi.org/10.1111/j.15406261.2006.00851.x

Cremers, M. \& Nair, V. B. (2005). Governance mechanisms and equity prices, Journal of Finance, 60(6), 2859-2894. https:// doi.org/10.1111/j.1540-6261.2005.00819.x

Doidge, C., Karolyi, A. G., \& Stulz, R. M. (2007). Why do countries matter so much for corporate governance? Journal of Financial Economics 86(1) 1-39. https://doi.org/10.1016/j. jifineco.2006.09.002

Eita, J. H. (2015, September). Role of Governance Indicator in Stock Market Development of Selected Sub-Sahara Economics. Paper presented at the Biennial Conference of economic Society of South Africa, Cape Town, South Africa

Frey, B. S., \& Waldenstrom, D. (2004). Markets work in war: World War II reflected in the Zurich and Stockholm bond markets. Financial History Review, 11, 51-67. https://doi.org/10.1017/ S0968565004000046

Giannetti, M., \& Koskinen, Y. (2010). Investor protection, equity returns, and financial globalization. Journal of Financial and Quantitative Analysis 45, 135-168. https://doi.org/10.1017/ S0022109009990524

Gompers, P., Ishii, L. \& Metrick, A. (2003). Corporate governance and equity prices, Quarterly Journal of Economics, 118, 107155. https://dx.doi.org/10.2139/ssrn.278920

Hooper, V., Sim, A. B., \& Uppal, A. (2009). Governance and stock market performance. Economic Systems, 33(2), 93-116. https:// doi.org/10.1016/j.ecosys.2009.03.001

Ismail, I., \& Suhardjo, H. (2001). The impact of domestic political events on an emerging stock market: the case of Indonesia. Proceedings of Asia Pacific Management Conference, 235-262.

Javed, A. Y., \& Ahmed, A. (1999). The Response of Karachi stock exchange to nuclear detonation. The Pakistan Development Review, 38, (4) 777-786. http://www.e3journals.org/cms/ articles/1342846725_Afzal.pdf

Kaufmann, D. \& Aart, K. (2017). World Governance Indicators. Retrieved from http://info.worldbank.org/governance/wgi/ Home/Documents
Krishnamurti, C., Sevic, A., \& Sevic, Z. (2005). Legal environment, firm-level corporate governance and expropriation of minority shareholders in Asia. Economic Change and Restructuring, 38 (8) 85-111. https://doi.org/10.1007/s10644-005-4524-4

Lee, C., \& Ng, D. (2004). Corruption and international valuation: Does virtue-pay? Cornell University working paper.

Lehkonen, H., \& Heimonen, K. (2015). Democracy, political risks and stock market performance. Journal of International Money and Finance, 59(1), 77-99. https://doi.org/10.1016/j. jimonfin.2015.06.002

Li, S. \& Filer, L. (2007). The effects of the governance environment on the choice of investment mode and the strategic implications, Journal of World Business, 42 (1), 80-98. https:// doi.org/10.1016/j.jwb.2006.11.006.

Lombardo, D. \& Pagano, M. (2006) Legal determinants of the return on equity. In: Oxelheim Lars (ed.) Corporate and Institutional Transparency for Economic Growth in Europe. Oxford, UK: Elsevier.

Lombardo, D., \& Pagano, M. (2000). Legal determinants of the return on equity. CSEF Discussion Paper 24, Naples. https:// doi.org/10.2139/ssrn.209310

Low, S.W., Kew, S. R., \& Tee, L.T. (2011). International evidence on the link between quality of governance and stock market performance. Global Economic Review 40(3), 361-384. https:// doi.org/10.1080/1226508X.2011.601646

Mauro, P. (1995). Corruption and growth. Quarterly Journal of Economics 110(3), 681-712. https://doi.org/10.2307/2946696

Milyo, J. (2012). Stock market reactions to political events: what can we learn about the efficacy of political connection? Working Paper No. 12-15. Washington DC: Mercatus Center, George Mason University. DOI: 10.1108/JEAS-03-2013-0011

Nguyen, C. T., \& Nguyen, M. H. (2019). Modeling Stock Price Volatility: Empirical Evidence from the Ho Chi Minh City Stock Exchange in Vietnam. Journal of Asian Finance, Economics and Business, 6(3) 19-26. https://doi.org/10.13106/ jafeb.2019.vol6.no3.19

Pesaran, M. H. \& Y. Shin (1998). An Autoregressive DistributedLag Modeling Approach to Cointegration Analysis. In: Steinar Strom (ed), Econometrics and Economic Theory in the 20th Century: The Ragnar Frisch Centennial Symposium, Cambridge University Press, New York, (pp. 371-413).

Scott, R.W. (2004). Institutional theory. In: George Ritzer (ed.), Encyclopedia of Social Theory, Thousand Oaks, CA: Sage. (pp. 408-414). http://dx.doi.org/10.4135/9781412952552.n155

Wei, S. J. (1997). How taxing is corruption on international investors? Working Paper 6030. Washington, DC: NBER. https://doi.org/10.3386/w6030

Yermack, D. (2006). Flights of fancy: Corporate jets, CEO perquisites, and inferior shareholder returns, Journal of Financial Economics, 80, 211-242. https://doi.org/10.1016/j. jfineco.2005.05.002 


\section{Appendices}

Appendix I: Panel unit root test

\begin{tabular}{|c|c|c|c|c|}
\hline Method & Statistic & Prob.** & Cross-sections & Obs \\
\hline \multicolumn{5}{|c|}{ Null: Unit root (assumes common unit root process) } \\
\hline Levin, Lin \& Chu t* & -8.94153 & 0.0000 & 6 & 60 \\
\hline Breitung t-stat & -0.43139 & 0.3331 & 6 & 54 \\
\hline \multicolumn{5}{|c|}{ Null: Unit root (assumes individual unit root process) } \\
\hline Im, Pesaran and Shin W-stat & -4.84427 & 0.0000 & 6 & 60 \\
\hline ADF - Fisher Chi-square & 41.6846 & 0.0000 & 6 & 60 \\
\hline PP - Fisher Chi-square & 38.2637 & 0.0001 & 6 & 66 \\
\hline
\end{tabular}

\section{Appendix II}

$$
\text { log_asi }
$$

\section{2}

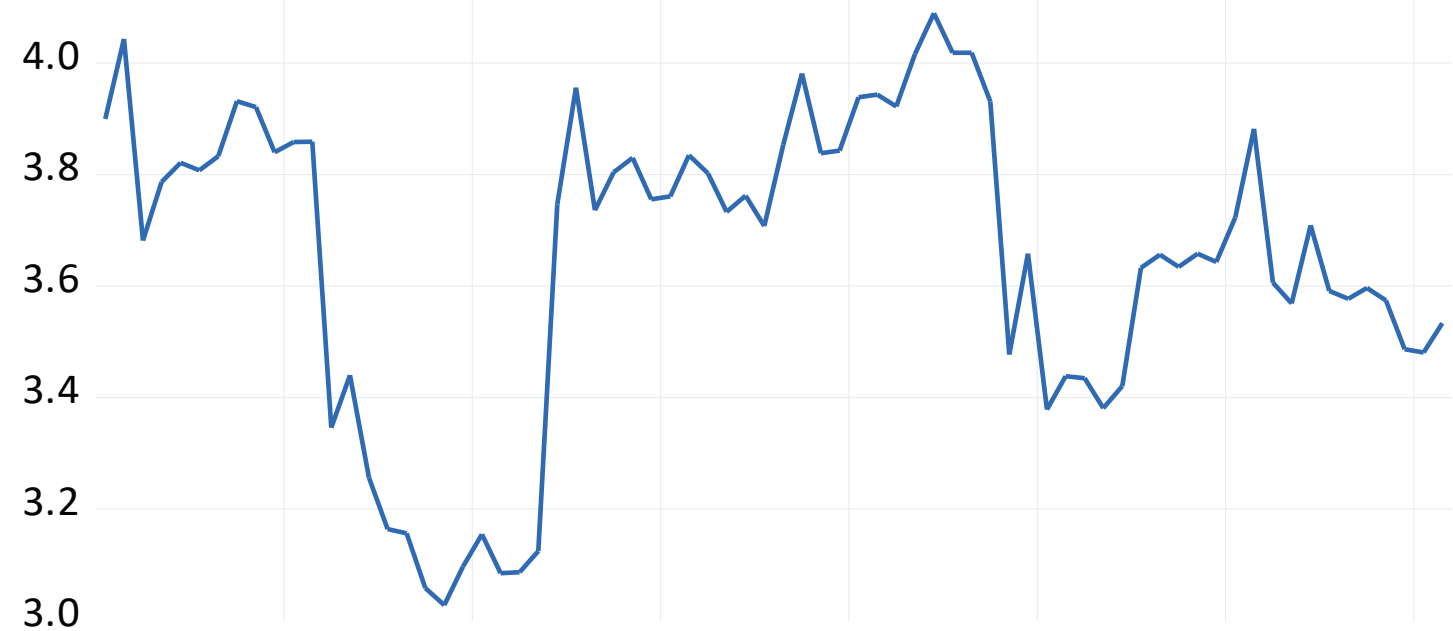

3.0

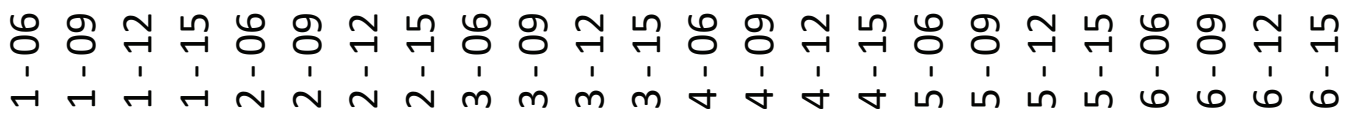




\section{Appendix III}

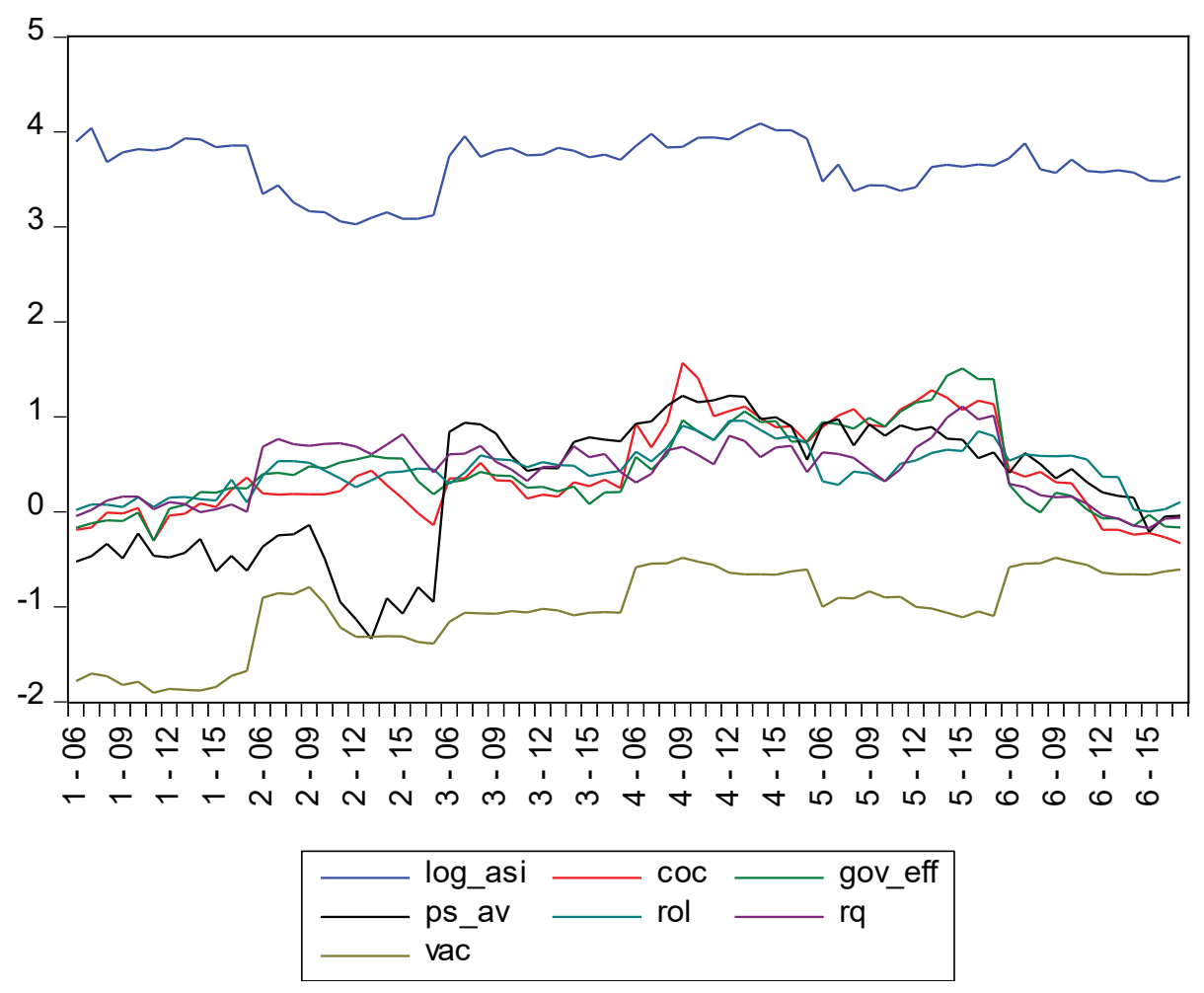

